\title{
EXAMINING THE PERFORMANCE OF TEACHER GRADUATES FROM LIMPOPO RURAL UNIVERSITY
}

\author{
K. L. Thaba-Nkadimene* \\ e-mail: Kgomotlokoa.thaba@ul.ac.za
}

\section{S. D. Mmakola*}

e-mail: Sharon.mmakola@ul.ac.za

*Department of Social Sciences and Economic and Management Sciences

University of Limpopo

Polokwane, South Africa

\section{ABSTRACT}

Schools in Limpopo Province are facing learners' underperformance, and a blame is levelled on poor teachers' performance. Teacher Education Centres that train educators for the Limpopo Province are also blamed for training teachers who fail to deliver quality teaching and learning because of their lack of necessary teaching skills that are required to improve learners' performance. The study aimed at examining the performance of teachers and how schools' contextual factors impact on their teaching practice. The main research question that drove the study is "what are possible causes of poor performance of teachers in Limpopo rural schools?" Critical Social Theory was used to understand the causes of poor performance of teachers, and the contextual factors that influence the teaching practice. Twelve teacher graduates from one rural Limpopo university were purposively sampled. The findings range from lack of teaching competencies; lack of school resources and infrastructure; and challenged home background. In conclusion, when teacher training has to be blamed for production of teachers who lack adequate teaching competencies, the Department of Education is blamed for not providing adequate school resources and infrastructure vital for the creation of conducive learning environment, and delivery of quality education and learning. This study recommends that improved working conditions in schools that enhances high levels of teachers' performance should be made.

Keywords: teachers' performance, teaching competencies, teaching practice, improved teaching and learning, student learning

\section{INTRODUCTION}

The research reports on possible causes of poor performance of teacher graduates from a rural university in Limpopo Province. Schools in Limpopo Province are facing learners' underperformance, and a blame is levelled on poor performance of teachers. Teachers play a significant role in the learning process and performance of learners. Research indicates a strong 
positive relationship between teachers and learners' performance (Košir and Tement 2013, 01). Dikgale $(2012,65)$ indicates that teachers' performance is equated to the level of training and qualifications offered. Based on Dikgale (2012) and Košir and Tement (2013), we then deduce that learners' performance is influenced by the level of teachers' preparedness in teacher education. This means that inadequate preparation of teachers in teacher training translates into poor performance of learners. This then shift the blame on poor learners' performance on teachers and teacher education. The blame results from teacher training institutions' failure in supplying schools in Limpopo Province with competent teachers who are capable of delivering quality teaching and learning and promoting learners' performance. Furthermore, research indicates that poor learners' performance emanates from the challenge of teachers with limited teaching competencies (Spaull 2012). Research further reveals that teachers lack necessary teaching skills that are required for adequate promotion of learners' performance (Spaull 2012; Modiba 2016). Thaba and Kanjere $(2014,537)$ allude to the above crisis situation by arguing that the crisis in the South African education system lies in a lack of the development of professional skills of teachers, and the prevailing low quality of education. They further argue that this can change by a well-equipped initial teacher training programme that produces an adequate number of competent teachers.

Apart from the challenges that are inherent within teachers and teacher education, the Department of Education has to be blamed for a lack of provisioning of school resources and facilities; and this leads to unbearable teaching and learning environment that fuels poor performance of learners in Limpopo schools. In addition to the above, research indicates that lack of facilities, unavailable learner support materials, lack of discipline, English as a medium of instruction, heavy workload due to rationalisation and redeployment of educators' make teachers' working conditions unbearable, and serve as great contributor towards poor learners' performance (Rammala 2009, iv). Despite having DBE as a contributor towards poor performance of learners in Limpopo schools, we strongly believe that lack of required teaching competencies among teachers is a significant contributor to Limpopo educational crisis. However, the focus of this study is on the examination of the performance of teachers, and how schools' contextual factors influence their teaching practice.

In order to examine such performance and how schools' contextual factors impact on their teaching practice, qualitative case study was conducted using one-to-one interviews to establish lived experiences and reflections of teachers graduates of one rural university in Limpopo Province. Critical Social Theory provided theoretical framework for this study. The study was driven by the main research questions, namely, "What are possible causes of poor performance of teachers in Limpopo rural schools". This study is of practical importance to teacher education 
and Department of Basic Education because it exposes and unveils teachers' competency gap and contextual factors that lead to compromised delivery of curriculum. We strongly believe that the quality of teaching personnel is a result of quality teacher training programme. Therefore, it is imperative for teacher training programmes to revisit exit outcomes as prescribed by the Minimum Requirements for Teacher Education Qualification (MRTEQ) policy (2015); and integrate the $21^{\text {st }}$ century competencies within their curriculum, for full preparation of future teachers who will be responsible for millennial and digital generation.

\section{BACKGROUND AND PROBLEM STATEMENT}

The swift response of the South African government in recognizing education as a fundamental human right has led to the declaration of compulsory basic education from Grade R to Grade 9. This transformation was driven by the United Nation's Millennium Goal number 2 that puts emphasis on the provision of education to all children of the world by 2015. Atieno, Simatwa and Ayodo (2012) put it clear when they highlight that access to quality education is recognized as a basic right by the Constitution of the Republic of South Africa, and it is considered as a catalyst for economic growth and human development. Similarly, the United State of America's response brought along compulsory education, namely; "No Child Left Behind movement".

Despite such a good move, available evidence indicates that most black learners receive poor school education (Spaull 2013b) and quality education for all becomes a far reached goal. In contrary, DBE puts it clear that basic education is the priority one in government; and regards quality of learning as related to development of all South Africans and the country (Department of Basic Education 2016). This situation in South Africa is best described by Spaull (2013a) when he highlights that there "is an on-going crisis in South African education, and that the current system is failing the majority of South Africa's youth". In support of the above, Modisaotsile (2012) echoed the same sentiments when saying that "there are many signs that there is a crisis in education".

The compromised education is the result of multiple factors, ranging from understaffing, under-trained and demotivated teachers, incompetent school managers; lack of school infrastructure such as classrooms, library, laboratories, running water, sanitation; and a lack of adequate learning materials (Thaba-Nkadimene 2017). Apart from stated hindrances to the provision of quality education in South African schooling system, the country is faced with economic meltdown emanating from recession and low economic growth. These two factors are major draw back towards attainment of quality education and as a result the country fails to meet its education obligations and poverty reduction plans. Therefore, South Africa as a developing country requires education for human development in order to improve its economic 
growth to fight the plight of poverty, unemployment and inequality (Modiba 2018). Other African states share similar challenges.

The challenges facing African states can be mitigated through human development. The upskilling and upgrading of African people's market related competencies can bring transformation to the whole continent. Hence, human development requires quality teachers' training programmes which are believed to bring required change in school going age and youth. Quality teachers are known to offer quality teaching and improved student learning (Leithwood and Jantzi 2006). South Africa, which is faced with poor black education, requires resources, and of utmost paramount quality teaching personnel. This means that the improvement of public education is possible through the placement of highly trained and competent teachers in all classrooms. In support, Desimone, Smith and Ueno (2006) and Modiba (2016) highlight the fact that competent teachers are most critical role players in attaining high levels of learners' achievement. The Department of Basic Education, in collaboration with the Department of Higher Education and Training initiated continuous teachers programme with the aim to improve quality teaching personnel who can offer quality teaching and improves student learning and achievement. Despite the progress made, there is still a challenge in the performance of teachers and learners in Limpopo province. Research reveals that most schools in South Africa are still underperforming (Spaull 2013a; 2013b); Horowitz 2014; Modiba 2016), despite prevailing interventions. Research indicates that the major cause of school underperformance is the results of unpredictable home environments of learners that are educationally unsupportive due to high levels of poverty, parents' low-level of education, high unemployment rate, child-headed families, emotional problems and issues relating to gender roles (Rammala 2009).

In lieu of the above, the problem this study investigated is poor performance of teachers in South African public schools. Therefore, the poor performance of learners manifests through poor performance of teachers in South African public schools. A gap exists in literature on the possible causes of poor performance of teachers from rural universities in Limpopo Province. This gap calls for studies of this nature to define and explore it; and find possible solution towards its mitigation. The study aimed at examining the performance of teachers and how schools' contextual factors influence their teaching practice.

\section{CRITICAL SOCIAL THEORY}

Critical Social Theory is used in this study because it provides philosophical and theoretical underpinnings required in the examination of the performance of teachers and how schools' contextual factors influence teaching practice in Limpopo rural schools. The primary objective 
of social critical theory is "the improvement of the human condition" (Ngwenyama and Bryson 1999, 352). As social critical theorists, we are aware and critical of what we see as pervasive inequalities and injustices (Freeman and Vasconcelos 2010) in our education system; and we see such circumstances perpetuated without proper government intervention in mitigating education crisis faced by South African black community Furthermore, the choice of critical social theory is informed by its capability and functionality in serving as "a theory of crisis"; "theory of education" and "theory of transformative action" (Freeman and Vasconcelos 2010, 7). It helps in understanding the severity and contribution of education crisis to the prevailing unbecoming circumstances of the future of black African children; the circumstances that cause education crisis in the country; and how education can serve as transformation tool to mitigate the plight of black South African. The plight of poverty, unemployment and inequality (Modiba 2018) that is striking the black South Africans in particular, can be addressed through social transformation; and human capacitation and emancipation offered by the delivery of quality education.

\section{RESEARCH METHODOLOGY AND DESIGN}

\section{Research paradigm and design}

This study is premised within the interpretivist paradigm, because it assists in "our understanding of the contemporary social world" (Chowdhury 2014). This paradigm acknowledges subjective within human action and understanding or reality and social school order (Chowdhury 2014) which is required to examine teachers' performance. This study taps on benefit of interpretivism that allows the use of researchers' experiences to construct and interpret a phenomenon such as performance of teachers (Thanh and Thanh 2015). Qualitative case study research design was adopted, because it allows for attainment of in-depth information from the research participants (Creswell and Plano Clark 2007). Furthermore, this design facilitates the exploration of a teachers' performance phenomenon within its context; and can be used as practice-based approach in developing educational theories, evaluating teacher training programs, and developing interventions to curb low levels of teachers' performance because this design is known for its flexibility and rigor (Baxter and Jack 2008).

\section{Sampling and instruments}

A total of 12 teachers were purposively selected from Limpopo schools to participate in individual interviews. Qualitative case study allows for the use of interviews in order to find indepth information about the performance of teachers. Interviews were based on their strength 
in eliciting narrative data and allow researchers to investigate people's views in greater depth (Kvale 2003; Alshenqeeti 2014). Qualitative data generated using interviews were analyzed using content and narrative analytical procedures. Narrative research analysis involves a detailed description of the case and the setting of the case within contextual conditions (Yin 2003, Creswell and Plano Clark 2007). Ethical procedures were followed that required approval from circuit offices, schools and research participants; and protection from harm.

\section{RESEARCH FINDINGS AND DISCUSSION}

This section reports on the research themes and findings that emanate from the empirical study and literature review. The research data resulted from the main research questions that was driving this study, namely; what are possible causes of poor teacher performance in South African public schools emerged with three main themes, namely, teaching competence; school related contextual factors; and home-related contextual factors.

\section{Teaching competence finding}

With regard to the teaching competency trend, the study reveals that teachers lack adequate levels of content and pedagogical knowledge with some pockets of best practice in some case schools. In majority of case schools, the participants reflected teaching incompetence and a lack of content knowledge, a lack of pedagogical knowledge; and a lack of digital literacies in particular, compromises teaching quality and students learning in particular. It is the responsibility of the Department of Basic Education and Department of Higher Education and Training to ensure placement of competent teachers occurs South African public schools. In support of the above, Guerriero (2013) indicates that "improving student outcomes is also about improving the quality of the teaching workforce". In support of this finding, Mashau, Mutshaeni and Kone's (2016) study revealed the main "capacity, quality, cooperation and relevance of teacher education" as major challenges that South African teacher education is faced with. Furthermore, the finding on a lack of teaching competence was put in perspective by Participant 7 who revealed important issues related to best teaching practice by pre-service and practicing teachers. Participant 7 puts it clear by highlighting that:

"my teaching practice is informed by what I have seen practiced by my teachers at schools and universities. If I have to reflect on what I am doing as a teacher in the school, it is the resemblance of my predecessors' teaching practices. I have studied best practices at the university and I know what it takes to become an outstanding teacher, however it was not modelled and I also fail to model what I know, and that was what I never saw nor experienced."

In support of what Participant 7 was saying, Participant 12 highlights that: 
"teaching is a practice-based profession, and modelling best teaching practices should not be just a lip service. As a teacher graduant, the prevailing conditions of shortage of teaching posts did not offer me a chance to select the school of my choice that is best performing school. The circumstances on the ground had forced me to be absorbed in the school I am. And I am stagnant here with limited chances of moving to greener pastures. If I can be given a choice today, I will choose a school with good disciplined and competent teachers whom I will emulate in my teaching practice. I was never mentored and I know I needed mentoring services that could add value to my teaching profession and my teacher development. Sometimes I fail to accept that I am working with the teaching personnel that does not respect and care for their profession and clientele. Contrarily, I want to care and take a full responsibility for my job, and I want to be a role model and mentor to novice and those aspiring to become teachers."

Modelling of best teaching practice by school teachers and university lecturers was regarded as important area in improving teaching practice of newly appointed teaching practitioners that include novice teachers. Becoming an outstanding teacher who possesses best teaching competencies, and who can offer quality teaching practice that positively is a desire for teachers who participated in this study. Furthermore, the participants indicate a need to belong or be part of best performing school that is educationally serviced by good disciplined; competent; and caring teachers.

The researchers strongly believe that teacher education is a corner stone of teacher performance and students' learning. As a result, it should be well-designed. In addition to the above, Florian (2013) reflects the most crucial areas in teacher education. In search for best teacher education programme Florian (2013) highlights that:

"there are many differences of opinion about the nature of the content knowledge student teachers should learn, as well as what and how they should learn about human variability."

The insertion above testifies the value attached to teacher education; and stresses its position as a bedrock of quality basic education. The extract reflects four significant areas of teacher education programme, namely teacher education curriculum; content or disciplinary knowledge; pedagogical knowledge; and knowledge of students particularly differences in learning styles and paces. Teacher education curriculum is crucial in developing a kind of teacher who possess necessary disciplinary knowledge and pedagogical knowledge competencies. Disciplinary and pedagogical knowledge are two different knowledge areas that define a teacher as a pedagogue and make teaching a distinct from other professions. Disciplinary knowledge refers to specific specialised subject matter relevant to teach a subject whereas, pedagogical knowledge refers to art and science of teaching that reflect principles, practices and methods of teaching (Department of Higher Education and Training 2015). Therefore, the stated finding that reflected the lack of content and pedagogical knowledge pose 
a serious challenge to teacher education and to teaching profession and fraternity as a whole. The content and pedagogical knowledge define a teacher as pedagogue from other professionals; and if these areas lack, then there is no teacher who should take charge of classroom activities and student learning.

Apart from the findings on a lack of disciplinary and pedagogical knowledge; a lack of teachers' digital literacies was also identified as a cause of poor teachers' performance. This finding was found to be a common challenge to all case schools. In understanding the dilemma teachers are faced with in relation to digital literacies, there is a need to get it from horse mouth. Participant 2 argues that:

"The use of digital technologies in teaching and learning delays my teaching progress. We need to cover certain content within certain dates and thoroughly prepare my learners for common tests. If I don't do this, my learners will not cope, and they will fail."

Contrarily, Participant 11 is a willing horse, but lacks necessary teaching and learning digital technologies. Instead Participant 11 states that:

"My school has no access to computer and internet, and I don't have necessary digital skills for future use of the systems for teaching and learning. I am planning to upskill my digital skills, and start my teaching and assessment online."

The challenge related to unavailability and lack of access to digital technologies becomes a hindrance to other teachers who are willing to venture into $21^{\text {st }}$ Century teaching and who would like to become relevant in using digital teaching and learning technologies environment for digital generation. For those who displays resistance to change character indicated their favor to continued use of traditional teaching methods and creating traditional learning environment instead of creating a platform for transition to digital learning environment. Lack of teachers' digital competencies is an indication that digital competencies were not attended to or reinforced during university years. The situation is made worse, when university lecturers as role models, lack digital competencies. The study conducted by Boshielo (2014) confirms that lecturers lack interest and digital competencies in using Blackboard as Learning Management System in supporting their lecturers, and improving student learning. This situation is prevalent despite the vast benefits that are brought along by such digital technologies, namely, creating assessment; online discussions; and management of large classes (Boshielo 2014).

\section{School contextual factors}

Apart from the research trend related to teaching competencies, school contextual factors emerged as second trend within possible causes of poor teachers' performance. This finding 
reveals that the contextual factors such as lack of school resources; a lack of proper infrastructure such as classrooms, libraries, computer centres; and commercial laboratories are still challenging many public schools in South Africa. A lack of adequate school resources and infrastructure was highlighted by majority of the participants. Participant 5 was very loud and clear by highlighting that:

"I am working in uninviting school environment where the staffroom and classroom are in one block which is dilapidated. My learners and some of the colleagues' lives are at risk. A little blowing wind can put a structure down. The school governing body and management written so many letters to the department for reconstruction of the building, but all in vain. In addition to rotten building structure, I struggle to get proper learning and teaching support materials (LTSM). I am made to use chalk and duster, like they are only ones available for teaching and learning. The school requested donations and fundraised for computer lab, and the business sector fails to come to our rescue after my Department dismally failed my school with proper LTSM."

Participant 5 was able to paint a good picture of the status of school buildings and LTSM that cause teachers poor performance. As identified above, lack of adequate LTSMs is regarded as a hindrance to teacher performance. This research finding on LTSM is supported by Moshoana and Thaba-Nkadimene's (2016) study that reveals a lack of books that are aligned to new schooling curriculum and other LTSM as a great challenge to many public schools. The challenge of lack of textbooks is a perennial to South African public schools. Research indicates that in 2007, majority of South African learners did not receive adequate learning material (Spaull 2012; Moloi and Chetty 2010).

Participant 5 alluded to lack of infrastructure as hindrance to their provision of quality teaching. This finding involves a lack of school infrastructure such as classrooms, toilets, libraries, laboratories and computer centers were identified as hindrances to quality teaching and learning. In support of this finding, Amsterdam (2010) findings reveal that schools still lack classroom space that result with learners' overcrowding; lack of sanitation facilities; playing grounds that are safe and free from hazards such as glass shards, rocks and thorns; and overcrowding and lack of classroom space. A lack of proper school infrastructure, classrooms in particular, results with uninviting and poor learning environment that contributes towards poor working environment that affects teachers' performance negatively.

\section{Home contextual factors}

The research trend that relates to challenged home background were found to hinder student learning. The home contextual factors that were identified as challenges to teachers' performance were abusive households; and poverty stricken households. A learner from an 
abusive household or background displays different behavioral patterns that are challenging to teachers, other learners and sometimes to themselves. Participant 2 reflects on his experiences and frustrations in working with learners with behavioral disorders. Participant 2 highlights that:

"After my completion at university I was allocated the class of Grade 11 repeating learners. At first I was not aware that they are all repeaters and I taught them like any other class. I noticed that learners in this class are grown up, and they are not easy to work with. Some of learners were displaying very strange behaviors to the extent that I recommended for social workers and psychological services. The intervention took time to unfold, but the good thing about it was that eight learners from a group of 59 were diagnosed with behavioral disorders and referrals were recommended."

The above insert quotation reveals the realities in South African public schools that learners are placed in wrong schools and were left unattended; and at the same rate teachers are expected to perform without necessary teaching competencies in teaching learners with behavioral disorders. Learners with behavioral disorders are denied good and quality education that can enable them to reach their full educational potential. This is only possible if there can be diagnosis of student who needs special attention in earlier years such as when they are in the Child Development Education and pre-schools; and allow such learners to be taught by practitioners with necessary knowledge and skills. In 2007 South Africa was found to have 10.9 per cent of children population aged 0-4 in 2007, with 1 per cent of them having a disability of some sort. In order to curb a problem of the late diagnosis, the Department of Basic Education should collaborate with Department of Health and Social Welfare to source social workers; educational psychologist and other health workers to help schools.

The last finding related to home contextual factor is poverty stricken households. The finding reveals that learners' household poverty contributes towards poor teacher performance. The problem with poverty is that parents' poverty directly impacts on children poverty. Participant 3 highlights that:

"learners from poverty household join their parents in the struggle for survival and this impacts their academic performance. Sometimes, learners come to school with empty stomach, and thanks to a programme on school learners catering, because after break, they will be full like other learners. Children from poverty stricken households are recruited into criminal activities that ranges from stealing, burglar, gangsterism, drug dealing and organized crimes. Sometimes they fall in trap of human trafficking that despise them with greener pastures and better working offers."

Participant 3 is supported by majority of research participants, and reveals that learners from poverty stricken households are faced with lack or staggering school progress; and a lack of 
concentration. This findings further reveals that sometimes such learners display aggression and violent behavioral patterns; and they are targets for gangs and criminal recruitments for stealing, buglaring, hijacking, drug dealing and human trafficking. There is evidence that lowincome children are caught up in their parents' economic struggles and as such they experience unmet needs; low-quality schools; and unstable circumstances (Ratcliffe 2015). The situation is scary when South Africa is faced with high rates of child poverty that is racially and spatially distributed among others is caused by lack of income and adult unemployment (Children's Institute 2018).

Research indicates that children from poor family backgrounds and poverty stricken households experience abuse that comes in different ways that ranges from physical assault, child battering, neglect, sexual abuse, child abandonment (Ngozi 2014). The study conducted by reveals that "child abuse affects leaners' academic performance" because majority of such learners develop anti-social and misdirected attitudes. In support, the findings of Azi and Saluhu (2016) reveals the devastating and life-long negative effects of abuse on the individual child and academic progress. Most often than not such learners tend to display behavioural disorder. Such learners need teachers who are well-equipped with instructional practices that includes high leverage practices and other pedagogical strategies relevant in teaching children with behavioral disorders (Cooper 2018).

\section{CONCLUSION}

The study concludes that a blame of low levels or poor teachers' performance in South African public schools cannot only be levelled on teacher education, but the government's contribution is significantly greater. In summary, three themes were identified, each with multiple findings. The first theme is related to a lack of teaching competencies and emerged findings involve lack of content knowledge; lack of pedagogical knowledge; and lack of digital literacies emerged. The second theme is related to the contextual factors, and it emerged with findings that ranges from lack of school resources; a lack of proper infrastructure such as classrooms, libraries, computer centres; and commercial laboratories are still challenging many public schools in South Africa. The last theme on home contextual factors emerged with abusive households; and poverty stricken household.

The recommendations on the basis of improving teaching competencies is that the curriculum of the teacher education curriculum should be well-designed and be integrated with $21^{\text {st }}$ Century skills. The Department should partner with private sector in addressing infrastructural backlog that ranges from installation of computers and internet; and building classrooms, toilets, library, laboratories, and playing grounds in rural public schools. 


\section{REFERENCES}

Alshenqeeti, H. 2014. Interviewing as a data collection method: A critical review. English Linguistics Research 3(1): 39.

Amsterdam, C. 2013. School infrastructure in South Africa: Views and experiences of educators and learners. Canada International Conference on Education, 1-5.

Atieno, L. S. J., E. M. W. Simatwa and T. M. O. Ayodo. 2012. Impact of family socio economic status on girl students' academic achievement in secondary schools in Kenya: A case study of Kisumu East District. International Research Journals 3(3): 297-310.

Azi, A. S. and A. I. Saluhu. 2016. The effect of child abuse on the academic performance of school children: Implication on the Nigerian Economy. Asia Pacific Journal of Education, Arts and Sciences 3(3): 23-27.

Baxter, P. and S. Jack. 2008. Qualitative case study methodology: Study design and implementation for novice researchers. The Qualitative Report 13(4): 544-559.

Boshielo, A. 2014. The impact of blackboard as a learning management system (LMS) for University of Limpopo students. Master of Business Administration. Polokwane, University of Limpopo.

Children's Institute. 2018. Review of research evidence on child poverty in South Africa. University of Cape Town. http://www.ci.uct.ac.za/news/review-research-evidence-child-poverty-sa (Accessed 28 November 2018).

Chowdhury, M. F. 2014. Interpretivism in aiding our understanding of the contemporary social world. Open Journal of Philosophy 4(03): 432.

Cooper, H. 2017. History 5-11: A guide for teachers. Routledge.

Creswell, J. W. and V. L. Plano Clark. 2007. Designing and conducting mixed methods research. Thousand Oaks: Sage Publications.

Department of Basic Education. 2016. Revised five-year strategic plan 2015-2020. Pretoria: Government Publishers.

Department of Higher Education and Training. 2015. National Qualifications Framework Act (67/2008): Revised policy on the minimum requirements for teacher education qualifications. Government Gazette 596 (38487).

Desimone, L. M., T. M. Smith and K. Ueno 2006. Are teachers who sustained, content-focused professional development getting it? An administrator's dilemma. Educational Administration Quarterly 42(2): 178-215.

Dikgale, M. M. 2012. Factors affecting academic performance of grade 12 learners in Mogalakwena Circuit. Masters in Public Administration Dissertation. Polokwane: University of Limpopo.

Florian, L. A. N. I. 2013. March. Preparing teachers to work with everybody: A curricular approach to the reform of teacher education. In FORUM: For promoting: 31-19.

Freeman, M. and E. F. S. Vasconcelos. 2010. Critical social theory: Core tenets, inherent issues. Critical social theory and evaluation practice. New Directions for Evaluation 127: 7-19.

Guerriero, S. 2013. Teachers' pedagogical knowledge and the teaching profession. OECD.

Horowitz, D. 2014. Courage to lead: Leadership lessons from Kilimanjaro. South Africa: Stonebridge Publishers.

Košir, K. and S. Tement. 2013. Teacher-student relationship and academic achievement: A cross-lagged longitudinal study on three different age groups. European Journal of Psychology of Education 29(3): $1-23$.

Kvale, S. 2003. The psychoanalytic interview as inspiration for qualitative research. In Qualitative research in psychology, ed. P. M. Camic, J. E. Rhodes and L. Yardley, 275-297. Washington, USA: American Psychological Association. 
Leithwood, K. and D. Jantzi. 2006. Transformational school leadership for large-scale reform: Effects on students, teachers, and their classroom practices. School Effectiveness and School Improvement 17(2): 201-227.

Mashau, T. S., H. N. Mutshaeni and L. R. Kone. 2016. Teacher education: The South African context. International Journal of Educational Sciences 14(1-2): 167-173.

Modiba, N. S. 2016. Lack of service delivery in the form of quality teaching and the Secondary School learner migration. SAAPAM Limpopo Chapter $5^{\text {th }}$ Annual conference proceedings, 174-179.

Modiba, N. S. 2018. Rebirth of African educational systems and its triple challenges in the 21 st century. Journal of Gender, Information and Development in Africa (JGIDA) 7(1): 185-204.

Modisaotsile, B. M. 2012. The failing standard of basic education in South Africa. Africa Institute of South Africa (AISA). Policy brief Number 72, March 2012.

Moloi, M. Q. and M. Chetty. 2010. The SACMEQ III Project in South Africa. A study of the conditions of schooling and the quality of education. SACMEQ (Southern and Eastern Africa Consortium for Monitoring Educational Quality) Educational Policy Research Series. Pretoria: Department of Basic Education.

Moshoana, M. D. and K. L. Thaba-Nkadimene. 2016. Promoting the culture of teaching and learning through effective curriculum management. Conference Proceedings. South African International conference on Education, 242-254.

Ngozi, O. J. 2014. Implications of child abuse on education of primary school students in Nigeria. IOSR Journal of Research and Method in Education 4(6): 10-16.

Ngwenyama, O. K. and N. Bryson. 1999. Making the information systems outsourcing decision: A transaction cost approach to analyzing outsourcing decision problems. European Journal of Operational Research 115(2): 351-367.

Rammala, M. S. 2009. Factors contributing towards poor performance of Grade 12 learners at Manoshi and Mokwatedi high schools. Masters of Development Dissertation. Polokwane: University of Limpopo.

Ratcliffe, C. 2015. Child poverty and adult success. Low-income working family. Urban Institute. https://www.urban.org/sites/default/files/publication/65766/2000369-Child-Poverty-and-AdultSuccess.pdf (Accessed 27 November 2018).

Spaull, N. 2012. Poverty and privilege: Primary school inequality in South Africa. Stellenbosch Economic Working Papers, 1-23.

Spaull, N. 2013a. South Africa's education crisis: The quality of education in South Africa 1994-2011, 1-65. Johannesburg: Centre for Development and Enterprise.

Spaull, N. 2013b. Poverty and privilege: Primary school inequality in South Africa. International Journal of Educational Development 33(5): 436-447.

Thaba, K. L. and M. M. Kanjere. 2014. Experiential learning in initial teacher education: Do schools have mentoring capacity? Mediterranean Journal of Social Sciences 5(27): 537-543.

Thaba-Nkadimene, K. L. 2017. Lessons learnt in the implementation of school leadership and managment programme by universities in Limpopo Province. Doctoral Thesis. Polokwane: University of Limpopo.

Thanh, N. C. and T. T. Thanh. 2015. The interconnection between interpretivism paradigm and qualitative methods in education. American Journal of Educational Science 1(2): 24-27.

Yin, R. K. 2003. Case study research: Design and methods. $3^{\text {rd }}$ Edition. Thousand Oaks: Sage Publishers. 